\title{
OPTIMASI PENJADWALAN PERKULIAHAN MENGGUNAKAN METODEAUTO GENERATE TIMETABLE DENGAN ARRAY
}

\author{
Hani Dewi Ariessanti ${ }^{1}$ \\ Dwi Sloria Suharti ${ }^{2}$ \\ Ary Budi Warsito ${ }^{3)}$ \\ Dosen STMIK Raharja Jurusan Sistem Komputer ${ }^{1}$, Universitas Muhammadiyah Tangerang ${ }^{2}$, Dosen \\ STMIK Raharja Jurusan Teknik Informatika ${ }^{3}$ \\ Email : hani.dewi@raharja.info,dsloria@gmail.com, arybudiwarsito@ raharja.info
}

Diterima: 4 Juli 2018/ Disetujui : 20 Juli 2018

\begin{abstract}
Scheduling is one of the many problems that has been done in research for many years. Problems preparing the schedule in college are about college scheduling. The timing process should be done for each semester, which is a tiring and time-consuming task. The overall allocation of events in timeslots and spaces is done by the course scheduling process by considering the list of hard constraints and soft constraints, so there is no conflict created in allocating the schedule. Therefore, it is necessary to create a lecture scheduling application that is able to facilitate and overcome the problems in organizing the lecture schedule. The proposed scheduling system design proposed in this study is to optimize the schedule of lectures using the Auto Generate Timetable method with arrays to find the best candidates for college scheduling with the aim of minimizing the conflict and optimizing the scheduling schedule. This method is based on the process of lecturing process that has been conducted in college. Every curriculum, space, day / time, is needed to arrange the schedule of students and lecturers as part of the scheduling variable that is the solution candidate. Then the process of adjusting to constraints has been made with various parameters. The research method is to collect the data, analysis, design, coding, testing and up to the maintenance phase by using the Waterfall System Development Lifecycle method. The waterfall model provides a life-cycle approach to the development of software systems in sequential or sequential form. So with the existence of this application, it is hoped that the arrangement of lectures will not find problems as a constraint in arranging the lecture schedule.
\end{abstract}

Keywords: Auto Generate Timetable, Array, constraint, waterfall, SDLC

\begin{abstract}
ABSTRAK
Penjadwalan adalah salah satu masalah yang telah banyak dilakukan dalam penelitian selama bertahuntahun. Masalah penyusunan jadwal di perguruan tinggi adalah seputar penjadwalan kuliah. Proses penentuan waktu harus dilakukan untuk setiap semester, yang merupakan tugas yang melelahkan dan memakan waktu. Alokasi keseluruhan kejadian di timeslots dan ruang dilakukan oleh proses penentuan penjadwalan kuliah dengan mempertimbangkan daftar hard constraint dan soft constraint, sehingga tidak ada konflik yang tercipta dalam mengalokasi jadwal tersebut. Oleh karena itu, perlu dibuat sebuah aplikasi penjadwalan perkuliahan yang mampu memudahkan dan mampu menanggulangi permasalahan dalam pengaturan jadwal perkuliahan. Rancangan sistem penjadwalan perkuliahan yang diusulkan dalam penelitian ini bertujuan untuk mengoptimalkan penyusunan jadwal perkuliahan menggunakan metodeAuto Generate Timetable dengan array untuk mencari kandidat terbaik penjadwalan kuliah dengan tujuan meminimalisir konflik dan mengoptimalkan penyusunan jadwal. Metode ini dilakukan berdasarkan pada mekanisme proses perkuliahan yang telah berjalan pada perguruan tinggi. Setiap
\end{abstract}


kurikulum, ruang, hari/waktu, dibutuhkan untuk menyusun jadwal mahasiswa dan dosen sebagai bagian dari variabel penjadwalan yang merupakan kandidat solusi. Kemudian dilakukan proses penyesuaian terhadap constraint-constraint yang telah dibuat dengan berbagai parameter. Metode penelitian yang dilakukan adalah dengan mengumpulkan data, analisis, desain, pengkodean, pengujian dan sampai tahap pemliharaan dengan menggunakan metode Siklus Hidup Pengembangan Sistem jenis waterfall. Model waterfall menyediakan pendekatan siklus hidup pengembangan sistem perangkat lunak dalam bentuk sekuensial atau terurut. Sehingga dengan adanya aplikasi ini, diharapkan pengaturan perkuliahan tidak menemukan permasalahan sebagai kendala dalam menyusun jadwal perkuliahan.

Kata Kunci: Auto Generate Timetable, Array, constraint, waterfall, SDLC

\section{PENDAhUlUAN}

Penjadwalan perkuliahan merupakan salah satu komponen penting dalam suksesnya pelaksanaan kegiatan belajar pengajar di perguruan tinggi, karena kegiatan penjadwalan dosen dan penjadwalan kuliah mahasiswa bergantung pada jadwal yang yang ada sehingga jadwal harus disusun dengan benar pada setiap semester. Pembuatan jadwal kuliah adalah kegiatan rutin yang dilakukan oleh perguruan tinggi pada tiap tahun ajaran. Di perguruan tinggi, program penjadwalan merupakan sesuatu yang penting dalam proses belajar mengajar, karena semua kegiatan dosen dan kegiatan mahasiswa bergantung pada jadwal yang ada, sehingga harus disusun dengan benar dan diperbaiki pada awal tahun akademik, sehingga nantinya tidak mengganggu aktifitas belajar mengajar antar dosen dan mahasiswa (Ariani, Fahriza, Prasetyaningrum, 2011). Terdapat beberapa aspek yang menjadi faktor penting adalah menyusunan jadwal perkuliahan diantaranya adalah tidak boleh adanya jadwal yang konflik misalnya ada seorang dosen yang jadwalkan mengajar di 2 kelas jelas berbeda pada saat yang bersamaan atau mahasiswa dijadwalkan di 2 matakuliah yang pada jam yang sama, ketersediaan waktu mengajar bagi dosen tidak tetap, keterbatasan ruangan, distribusi mata kuliah yang merata disetiap minggunya. Selain itu kendala yang terjadi adalah pada penyusunan penjadwalan kuliah masalah dari segi mahasiswa, keterbatasan jumlah dosen untuk mengajar kuliah. Selain itu ketersediaan kelas hingga kegiatan belajar yang dilaksanakan yang ini menjadi permasalahan diatas biasanya dikenal dengan University Timetabling Problem (UTP).

Berdasarkan beberapa aspek diatas maka diperlukan proses pembuatan jadwal tidak terlalu banyak atau meminimalkan constraint maka sehingga diperlukan optimasi yang dapat diterapkan dalam membuat membuat penjadwalan kuliah. Optimasi ini tidak bisa sepenuhnya menghasilkan hasil yang optimal tapi mendekati optimal. Ada beberapa metode optimasi yang sering digunakan untuk menyelesaikan penjadwalan dengan keunggulan masing-masing. (Aziz, 2015) Metode tersebut antara lain: Ant Colony, Simulated Anneling, Genetic Algorithm. Adapun kelebihan Ant Colony adalah dapat diterapkan secara sempurna dengan perubahan minimal ke permasalahan optimasi kombinasi, Simulated Anneling memiliki keunggulan lebih cepat dalam menyelesaikan iterasinya sedangkan Genetic Algorithm dapat digunakan untuk mencari berbagai solusi persoalan yang ada di dunia nyata. Selain itu beberapa penelitian sebelumnya telah dilakukan komparasi antara Algoritma Genetika dengan Algoritma Palgunadi untuk penjadwalan mata kuliah (Yudihartanti, Syukur, \& Wahono, 2011). Penelitian ini telah menghasilkan sebuah kombinasi algoritma genetika dan algoritma palgunadi dengan dihasilkannya perbaikan proses heuristik dari Algoritma Genetika dibuktikan dengan semakin baiknya nilai fitnessnya yang dihasilkan dan semakin sedikit waktu proses yang dibutuhkan. (Siswono, 2013). Selain itu telah 
dilakukan analisa terhadap perbandingan Metode Mamdani dan Metode Sugeno dalam penjadwalan mata kuliah dimana terdapat perbedaan pada proses yang dilakukan misalnya pada proses implikasi agregasi dan proses defuzzifikasinya. Pada proses ujicoba dengan dataset didapatkan bahwa hasil komparasi menunjukkan bahwa metode Mamdani mempunyai tingkat ketepatan yang dibandingkan dengan metode sugeno (Yudihartanti et al., 2011).

Pada penelitian ini diusulkan menggunakan Auto Generate timetable dengan Array Penggunaan Auto Generate timetable merupakan metode optimasi yang digunakan untuk penjadwalan perkuliahan untuk memecahkan masalah optimasi multidimensi dengan waktu proses yang lebih cepat. Metode penelitian yang dilakukan adalah dengan mengumpulkan data, analisis, desain, pengkodean, pengujian dan sampai tahap pemliharaan dengan menggunakan metode Siklus Hidup Pengembangan Sistem atau jenis waterfall. Model waterfall menyediakan pendekatan alur hidup perangkat lunak secara sekuensial atau terurut. Sehingga dengan adanya aplikasi ini, diharapkan pengaturan perkuliahan tidak menemukan permasalahan sebagai kendala dalam menyusun jadwal perkuliahan.

\section{METODE PENELITIAN}

Untuk membangun Aplikasi penjadwalan mata kuliah dengan metode auto generate timetable dengan array, metode penelitian yang digunakan meliputi Metode Pengumpulan Data, Metode Pengembangan Sistem dan pengembangan antar muka pengguna (user interface).

\section{Metode Pengumpulan Data}

Tahap pertama peneliti melaksanakan observasi (pengamatan) di salah satu kampus di Tangerang dengan cara mengumpulkan data, informasi dan mempelajari catatan serta dokumen yang ada mengenai prosedur penjadwalan perkuliahan. Selain pengamatan langsung dilakukan teknik pengumpulan data melalui wawancara mendalam (indept interview), Focus Group Discussion (FGD) dan studi dokumenter.

Berdasarkan data pertama ini akan dirancang (desain) dan diimplementasikan sistem penjadwalan perkuliahan menggunakan metode auto generate timetable dengan array yang diujicobakan di salah satu kampus di Tangerang sebagai objek penelitiannya. Pada tahap kedua peneliti melaksanakan kegiatan kebutuhan untuk untuk penjadwalan perkuliahan seperti hard constraint yang berhubungan dengan kepuasan dalam menghasilkan jadwal yang fisibel, soft constraint yang berhubungan dengan kualitas sistem penjadwalan, dan parameter seperti: ruang, waktu, dosen, mahasiswa, kurikulum.

Strategi kegiatan penelitian ini akan dilakukan dengan mekanisme seperti terlihat dalam fishbone diagram berikut ini: Gambar 1. Diagram Fishbone Penelitian Metode Pengembangan Sistem Metode penelitian yang digunakan adalah metode Siklus Hidup Pengembangan jenis Waterfall yang cocok untuk menggambarkan sistem. 


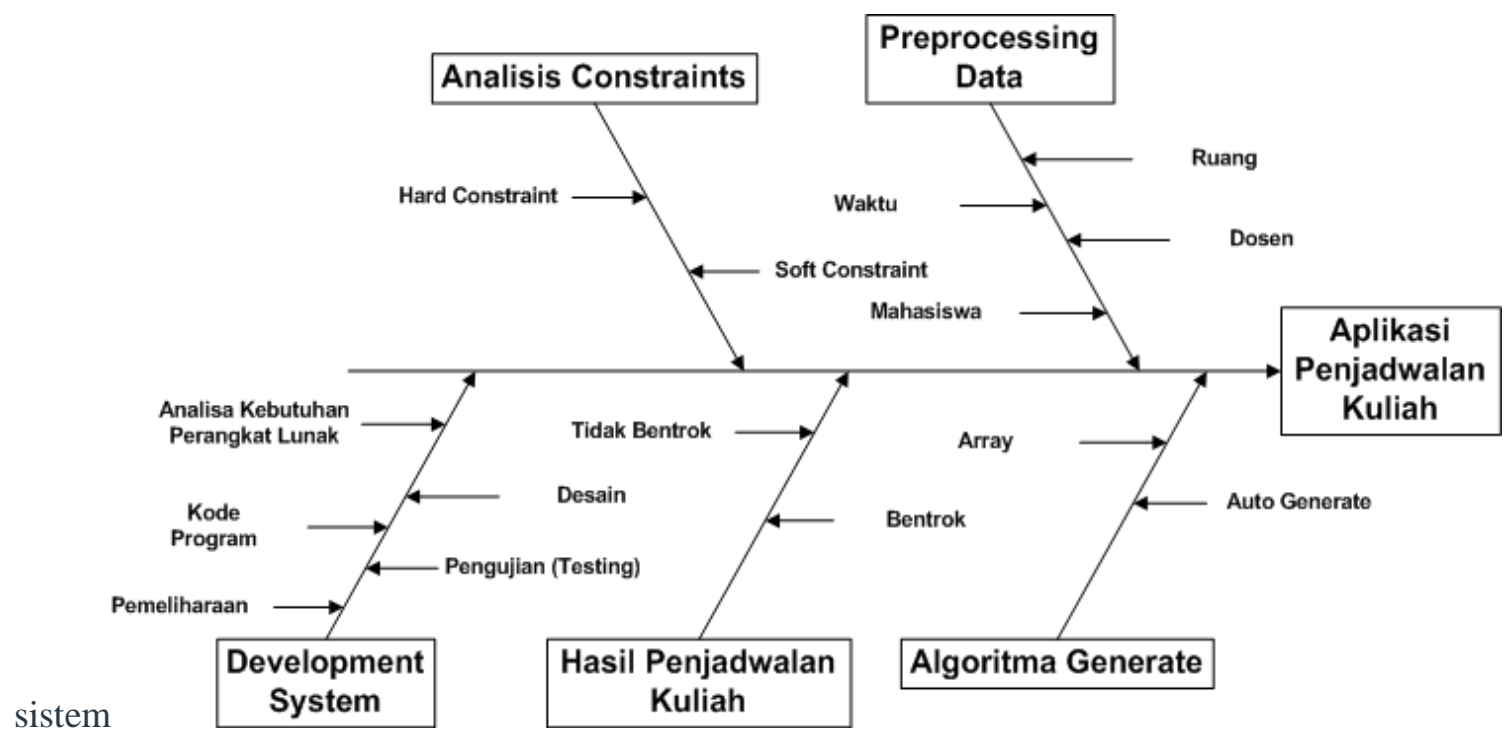

Gambar 1. Diagram Fishbone Penelitian

\section{Metode Pengembangan Sistem}

Metode penelitian yang digunakan adalah metode SDLC (System Development Life Cycle) jenis Waterfall yang cocok untuk menggambarkan sistem. Menurut Pressman (Pressman, 2010), model Waterfall atau sering disebut model sekuensial linier atau alur hidup klasik, menyediakan pendekatan alur hidup perangkat lunak secara sekuensial atau terurut dimulai dari Communication, Planning, Modeling, Construction, dan Deployment seperti yang disajikan pada gambar 3.2

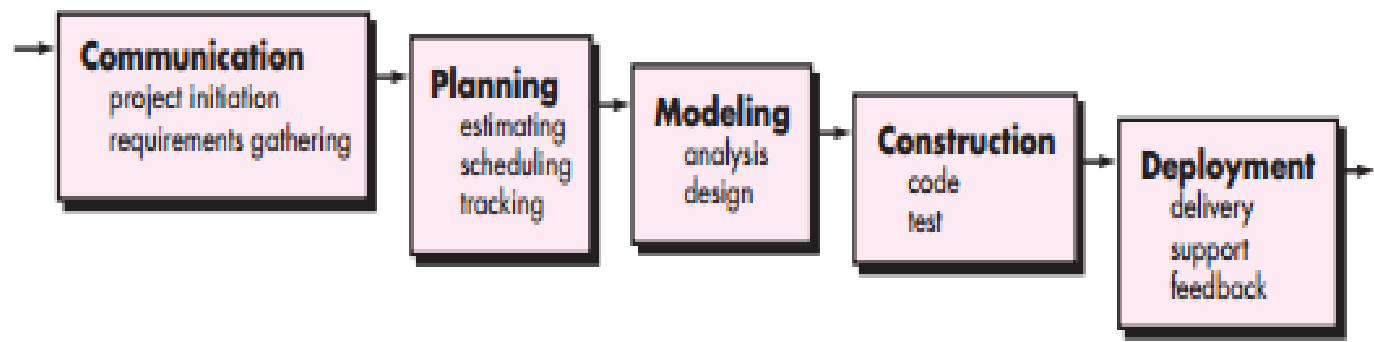

Gambar 2. Model Waterfall

Langkah-langkah model Waterfall adalah sebagai berikut:

1. Communication, terdiri dari: Project Initiation dan Requirements Gathering

2. Planning, terdiri dari: estimating, scheduling, tracking.

3. Modeling, terdiri dari: Analysis dan Design

4. Construction, terdiri dari: Code dan Test.

5. Deployment, terdiri dari: Delivery, Support dan Feedback.

\section{Prototipe Antarmuka Pengguna}

Antarmuka sistem dirancang terdiri dari beberapa form antarmuka yang berfungsi untuk antarmuka pengisian data. Rancangan antarmuka aplikasi ini meliputi:

1. Rancangan form Pengolahan Data Mata Kuliah 
Dalam Rancangan ini berisikan informasi Kode, nama mata kuliah dan jumlah SKS yang akan diambil. Dimana dalam form tersebut disediakan menu edit yang dapat digunakan oleh user atau pengguna.

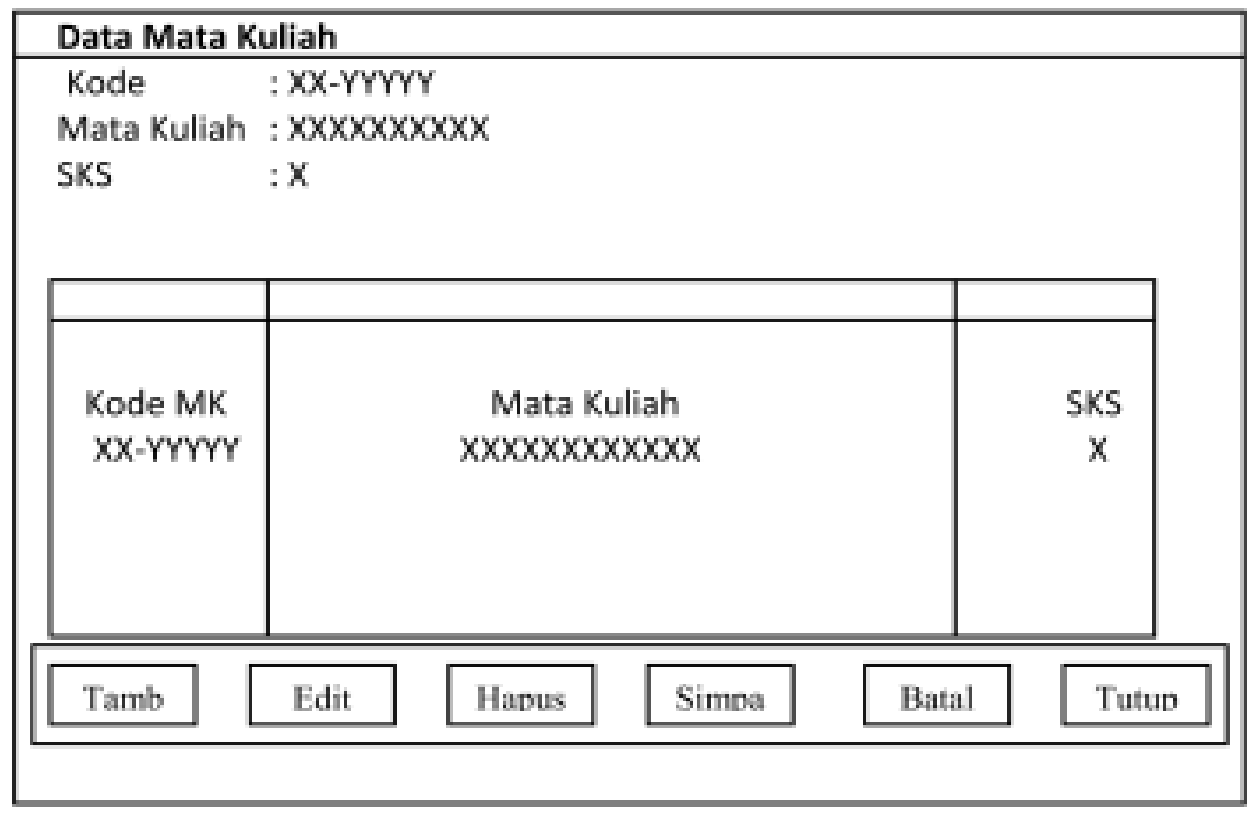

Gambar 3. Antarmuka Pengolahan Data Mata Kuliah

2. Rancangan form Pemasukan Data Ruangan

Dalam Rancangan ini berisikan informasi Kode, nama ruangan dan keterangan. Dimana dalam form tersebut disediakan menu edit yang dapat digunakan oleh user atau pengguna.

\begin{tabular}{|c|c|c|c|c|}
\hline \multicolumn{5}{|l|}{ Data Ruangan } \\
\hline \multirow{3}{*}{$\begin{array}{l}\text { Kode Ruangan } \\
\text { Nama Ruangan } \\
\text { Keterangan }\end{array}$} & \multicolumn{4}{|l|}{$: \mathrm{XXXX}$} \\
\hline & \multicolumn{4}{|l|}{$: x \times X X X X X X$} \\
\hline & \multicolumn{4}{|l|}{ : XXXXXXXXXXXX } \\
\hline \multirow{2}{*}{\begin{tabular}{|c|} 
Kode Ruangap \\
$\mathrm{XXXX}$
\end{tabular}} & Nama Ruangan & \multicolumn{3}{|c|}{ Keterangan } \\
\hline & $x \times X X X X X X X X X X$ & \multicolumn{3}{|c|}{$\mathrm{x} \times x \times x \times x \times x \times x \times x x$} \\
\hline Tamb & Hapu & Simp & Batal & $\mathrm{Tu}$ \\
\hline
\end{tabular}

Gambar 4. Antarmuka Pemasukan Data Ruangan

3. Rancangan form Pengolahan Data Set Mata Kuliah

Dalam Rancangan ini berisikan informasi Kode mata kuliah, kode dosen, durasi pelaksanaan mata kuliah dan keterangan. Dimana dalam form tersebut disediakan menu edit yang dapat digunakan oleh user atau pengguna. 




Gambar 5. Antarmuka Pengolahan Data Set Mata Kuliah

4. Rancangan form Pengolahan Data Set Waktu kuliah

Dalam Rancangan ini berisikan informasi hari, jam mulai dan selesai pelaksanaan mata kuliah juga keterangan. Dimana dalam form tersebut disediakan menu edit yang dapat digunakan oleh user atau pengguna.

\begin{tabular}{|c|c|c|c|c|c|}
\hline \multicolumn{6}{|c|}{ Dost Set Wiltu Kullah } \\
\hline 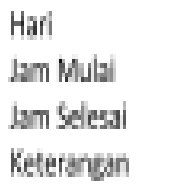 & \multicolumn{5}{|c|}{ 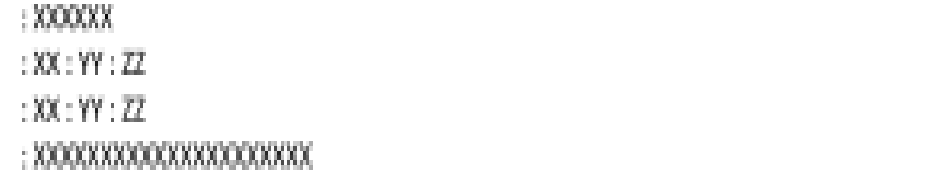 } \\
\hline Hari & Jam Muai & \multicolumn{2}{|c|}{ am Selexai } & \multicolumn{2}{|l|}{ Keteranpan } \\
\hline$x x x y$ & $X X: X X: X X$ & \multicolumn{2}{|c|}{$X X: X X: X$} & \multicolumn{2}{|c|}{$x \times x \times x \times x \times x \times x \times x \times$} \\
\hline Tamha & Fillit & Henis & Simn:m & Ratal & Tutun \\
\hline
\end{tabular}

Gambar 6. Antarmuka Pengolahan Data Set Waktu Kuliah 
ISSN : 1978 -8282

5. Rancangan form soft Constraint Waktu Kuliah

\begin{tabular}{|l||l|}
\hline SENIN DJam Ke] & SELASA Dam Ke] \\
\hline$\square 08: 00-08: 50[1]$ & $\square 08: 00-08: 50[1]$ \\
\hline$\square 08: 50-09: 40[2]$ & $\square 08: 50-09: 40[2]$ \\
\hline$\square 09: 40-10: 30[3]$ & $\square 09: 40-10: 30[3]$ \\
\hline$\square 10: 30-11: 20[4]$ & $\square 10: 30-11: 20[4]$ \\
\hline$\square 11: 20-12: 10[5]$ & $\square 11: 20-12: 10[5]$ \\
\hline$\square 12: 10-13: 00[6]$ & $\square 12: 10-13: 00[6]$ \\
\hline$\square 13: 00-13: 50[7]$ & $\square 13: 00-13: 50[7]$ \\
\hline$\square 13: 50-14: 40[8]$ & $\square 13: 50-14: 40[8]$ \\
\hline$\square 14: 40-15: 30[9]$ & $\square 14: 40-15: 30[9]$ \\
\hline$\square 15: 30-16: 20[10]$ & $\square 15: 30-16: 20[10]$ \\
\hline$\square 16: 20-17: 10[11]$ & $\square 16: 20-17: 10[11]$ \\
\hline$\square 17: 10-18: 00[12]$ & $\square 17: 10-18: 00[12]$ \\
\hline$\square 18: 30-19: 20[13]$ & $\square 18: 30-19: 20[13]$ \\
\hline$\square 19: 20-20: 10[14]$ & $\square 19: 20-20: 10[14]$ \\
\hline$\square 20: 10-21: 00[15]$ & $\square 20: 10-21: 00[15]$ \\
\hline All & $\square A l l$ \\
\hline
\end{tabular}

\begin{tabular}{|l|l|}
\hline RABU [Jam Ke] & KAMIS Jam Ke] \\
\hline$\square 08: 00-08: 50[1]$ & $\square 08: 00-08: 50[1]$ \\
\hline$\square 08: 50-09: 40[2]$ & $\square 08: 50$ - 09:40 [2] \\
\hline$\square 09: 40-10: 30[3]$ & $\square 09: 40-10: 30[3]$ \\
\hline$\square 10: 30-11: 20[4]$ & $\square 10: 30-11: 20[4]$ \\
\hline$\square 11: 20-12: 10[5]$ & $\square 11: 20-12: 10[5]$ \\
\hline$\square 12: 10-13: 00[6]$ & $\square 12: 10-13: 00[6]$ \\
\hline$\square 13: 00-13: 50[7]$ & $\square 13: 00-13: 50[7]$ \\
\hline$\square 13: 50-14: 40[8]$ & $\square 13: 50-14: 40[8]$ \\
\hline$\square 14: 40-15: 30[9]$ & $\square 14: 40-15: 30[9]$ \\
\hline$\square 15: 30-16: 20[10]$ & $\square 15: 30-16: 20[10]$ \\
\hline$\square 16: 20-17: 10[11]$ & $\square 16: 20-17: 10[11]$ \\
\hline$\square 17: 10-18: 00[12]$ & $\square 17: 10-18: 00[12]$ \\
\hline$\square 18: 30-19: 20[13]$ & $\square 18: 30-19: 20[13]$ \\
\hline$\square 19: 20-20: 10[14]$ & $\square 19: 20-20: 10[14]$ \\
\hline$\square 20: 10-21: 00[15]$ & $\square 20: 10-21: 00[15]$ \\
\hline$\square A l l$ & $\square A l l$ \\
\hline
\end{tabular}

\begin{tabular}{|l|l|}
\hline JUMAT Dam Ke] & SABTU [lam Ke] \\
\hline$\square 08: 00-08: 50[1]$ & $\square 08: 00-08: 50[1]$ \\
\hline$\square 08: 50-09: 40[2]$ & $\square 08: 50-09: 40[2]$ \\
\hline$\square 09: 40-10: 30[3]$ & $\square 09: 40-10: 30[3]$ \\
\hline$\square 10: 30-11: 20[4]$ & $\square 10: 30-11: 20[4]$ \\
\hline$\square 11: 20-12: 10[5]$ & $\square 11: 20-12: 10[5]$ \\
\hline$\square 12: 10-13: 00[6]$ & $\square 12: 10-13: 00[6]$ \\
\hline$\square 13: 00-13: 50[7]$ & $\square 13: 00-13: 50[7]$ \\
\hline$\square 13: 50-14: 40[8]$ & $\square 13: 50-14: 40[8]$ \\
\hline$\square 14: 40-15: 30[9]$ & $\square 14: 40-15: 30[9]$ \\
\hline$\square 15: 30-16: 20[10]$ & $\square 15: 30-16: 20[10]$ \\
\hline$\square 16: 20-17: 10[11]$ & $\square 16: 20-17: 10[11]$ \\
\hline$\square 17: 10-18: 00[12]$ & $\square 17: 10-18: 00[12]$ \\
\hline$\square 18: 30-19: 20[13]$ & $\square 18: 30-19: 20[13]$ \\
\hline$\square 19: 20-20: 10[14]$ & $\square 19: 20-20: 10[14]$ \\
\hline$\square 20: 10-21: 00[15]$ & $\square 20: 10-21: 00[15]$ \\
\hline$\square A l l$ & $\square A l l$ \\
\hline
\end{tabular}

Gambar 7. Antarmuka Soft Constraints Waktu Kuliah

6. Rancangan Form Hasil Generate (Pembangkitan) Penggunaan Ruang Kelas Terhadap Waktu (Timeslot) 
ISSN : 1978 -8282

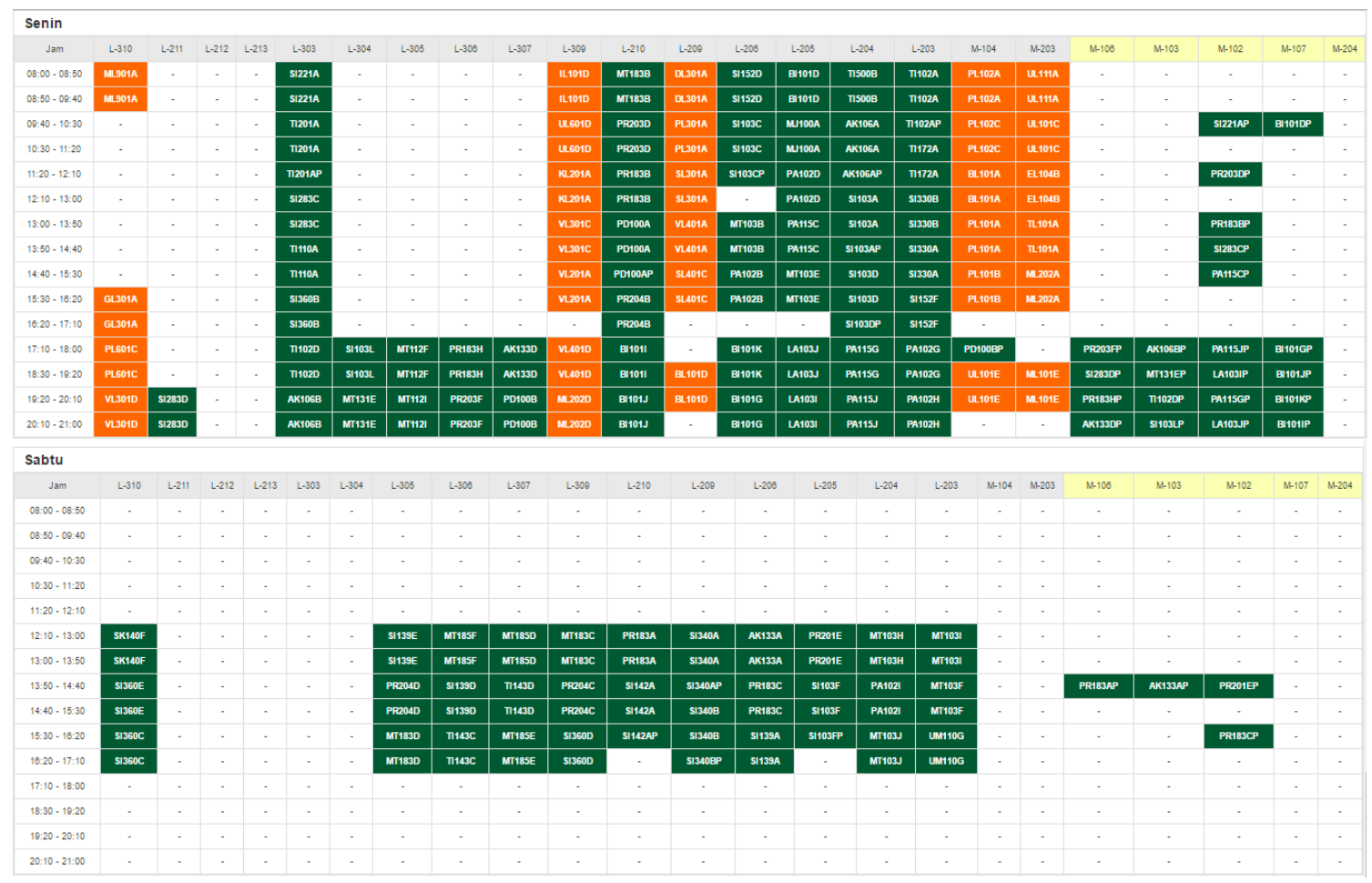

Gambar 8. Antarmuka Hasil Generate (Pembangkitan) Penggunaan Ruang Kelas terhadap waktu (Timeslot)

\section{PEMBAHASAN}

\section{Timetable}

Timetable merupakan alokasi subjek yang memiliki kendala untuk ditempatkan pada ruang waktu (Gani, 2004) permasalahan pada timetable cukup luas. Masalah ini ada pada keseharian kehidupan, pendidikan, kesehatan, transportasi, olahraga dan perusahaan produksi. (Chu \& Chen, 2006). Proses penyelesaian timetable yang optimal cukup rumit dan memakan waktu jika diselesaikan secara manual(Norberciak, 2008). Dari permasalahan tersebut, diperlukan metode yang dapat menyelesaikan timetable dengan cepat dan presisi.

Telah banyak upaya peneliti untuk mendesain perangkat lunak yang dapat menciptakan timetable secara otomatis. Tetapi, sampai saat ini belum ada yang secara penuh menghasilkan solusi yang optimal. Selain itu juga masih belum memungkinkan untuk menciptakan timetable secara otomatis dimana semua kendala terselesaikan dengan baik. (Kumar, Sharma, \& Mehta, 2012).

Ada beberapa variasi metode dari tujuan pemecahan masalah dalam pembuatan timetable dan pembuatan schedule (Norberciak, 2008). Variasi ini dibagi menjadi empat tipe :

a) Metode Sekuensial, metode ini memberi perintah kepada event dengan menggunakan domain heuristik dan memasukkan event secara berurutan ke dalam periode waktu yang valid atau disebut juga timeslot dimana tidak ada event dalam setiap periode yang saling bermasalah.

b) Metode cluster, pada metode ini event masuk ke dalam cluster dimana setiap dua event masuk ke dalam cluster khusus. Kekurangan utama pendekatan ini ialah cluster dari event terbentuk dari awal dan bersifat fix / tetap dan akan menghasilkan kualitas timetable yang kurang baik.

c) Metode berbasis kendala, Metode berbasis kendala, pada metode ini, kendala yang ada terbentuk dari beberapa variabel domain yang terbatas tergantung dengan sumber daya seperti periode waktu dimana timetable ditetapkan untuk memenuhi sejumlah kendala. Pada metode berbasis kendala, dapat terjadi dimana tidak semua kendala dapat terpenuhi. 
d) Metode Metaheuristik, variasi dari pendekatan metaheuristik untuk menyelesaikan timetable yaitu, Simulated Annealing (SA), Tabu Search, Evolutionary Algorithm, dan pendekatan lain. Metode metaheuristik dimulai dengan satu atau lebih solusi awal dan akan melakukan strategi pencarian untuk mendapatkan solusi yang optimal. Metode ini juga berupaya untuk menghindari localoptima. Pada masalah timetable yang lebih spesifik seperti pada perkuliahan, ada beberapa sesi pada satu hari.

Pada masalah timetable yang lebih spesifik seperti pada perkuliahan, ada beberapa sesi pada satu hari. Ada beberapa hari kuliah, yang berarti ada cukup banyak baris dan kolom tabel. Jika dalam sehari ada empat sesi dan dalam seminggu ada lima hari kuliah, sedangkan kampus memiliki empat 6 ruang kuliah, maka ada delapan puluh kolom yang akan terbentuk dalam tabel dari timetable perkuliahan.

Metode-metode yang pernah digunakan untuk menyelesaikan timetable adalah Traditional Forward Checking, Algoritma Genetik (GA), PSO (Chu \& Chen, 2006), Metaheuristic(Gani, 2004). Traditional Forward Checking membutuhkan waktu hitungan jam untuk menyelesaikan timetable (Montero, 2011)Pada masalah nyata, metode PSO dapat menyelesaikannya dalam waktu yang cepat(Montero, 2011).

Dalam penerapan PSO untuk masalah timetable universitas, urutan pemilihan mata kuliah dianggap sebagai partikel, dan tabel mata kuliah dapat dianggap sebagai suatu ruang waktu yang terdiri atas beberapa dimensi. Tujuan utama pada perhitungan untuk mencari timetable yang optimal ialah untuk meminimalkan pelanggaran terhadap kendala.

\section{Constraints}

Berdasarkan jenisnya, ada 2 jenis kendala, yaitu kendala yang bersifat tegas (hard constraints) dan kendala yang bersifat lemah (soft constraint) (Gani, 2004)(Montero, 2011). Kendala yang bersifat tegas (hard constraint) harus dipenuhi, sehingga tidak boleh terjadi pelanggaran terhadap kendala ini. Sedangkan kendala yang bersifat lemah tidak harus dipenuhi. Kendala ini lebih rumit diselesaikan daripada yang bersifat tegas. (Chu dkk, 2006).

Permasalahan bervariasi dari satu institusi ke institusi lain, namun sebagian besar pada time constraints yang serupa.(Islam, T., Shahriar, Z., Perves, M.A. and Hasan, 2016). Selain itu untuk jenis Constraints secara pemenuhan prioritasnya, constraints dapat dibedakan menjadi 2 bagian, yaitu (Poole, L., David, Alan K., 2010):

Selain itu untuk jenis Constraints secara pemenuhan prioritasnya, constraints dapat dibedakan menjadi 2 bagian, yaitu (Poole, L., David, Alan K., 2010):

1. Hard Constraints : adalah persyaratan yang harus dipenuhi dan tidak boleh dilanggar dalam pembuatan penyelesaian masalah.

2. Soft Constraints : adalah persyaratan tambahan yang biasanya menrupakan sebuah permintaan khusus, tanpa adanya konsekuensi fatal jika tidak terpenuhi. Menentukan Constraints

\section{Menentukan Constraints}

Untuk menentukan isi sebuah variabel yang hendak diisi, dapat dilakukan melalui dua cara yaitu(Poole, L., David, Alan K., 2010):

\section{Most Constrained Variable}

Penentuan Variable yang pertama diisi dan berikutnya dimulai dari variabel yang paling banyak mengandung constraint.

\section{Least Constrained Variable}

Penentuan variabel yang pertama diisi dan berikutnya dimulai dari variabel yang paling sedikit mengandung constraint.

\section{Generate(Pembangkitan)}

Permasalahan penjadwalan yang mengaitkan antara keinginan pribadi pekerja dengan ketersediaan jam kerja dalam organisasi dibahas dalam (Gunawan \& Toba, 2016) mengusulkan agar setiap keinginan pribadi tersebut dijadikan sebagai hal yang dicari solusinya pada tahap terakhir pada saat jadwal 
diverifikasi oleh tim dalam organisasi. Konsep yang ditawarkan dalam (Gunawan \& Toba, 2016) dengan membuat modul-modul yang terpisah antara pembangkitan jadwal awal, perbaikan under dan overstaffing dalam shift jam kerja, dan kemudian verifikasi keinginan pribadi dari pekerja. Hal tersebut dianggap cocok untuk dilakukan dalam konteks jadwal pekerja dalam organisasi dalam jumlah pekerja cukup banyak karena dapat mengalokasikan jadwal pada pekerja lain.

\section{Array}

Array sebagai struktur data yang paling sederhana dapat berdimensi satu atau yang disebut dengan larik, serta dapat juga berdimensi dua atau yang disebut dengan matriks. Matriks merupakan array dua dimensi. Array adalah koneksi data yang tipenya sama, tersusun dalam bentuk arus berurutan dan jumlah elemen atau datanya tidak berubah sesuai deklarasi awal. Berdasarkan konvensi, indeks pertama adalah baris, indeks kedua adalah kolom. (Putri, 2014).

\section{Kesimpulan}

1. Berdasarkan hasil survey pendahuluan yang dilakukan dalam sistem penjadwalan dan formulir kartu rencana studi yang diterima oleh mahasiswa dan program studi ter identifikai beberapa permasalahan, antara lain :

a) Dalam antrian terjadi penumpukan antrian yang tinggi sehingga tetrjadi penumpukan user yang berakibatkan kinerja sistem menjadi loading yang tinggi dan berujung pada hang dan bahkan crashnya sistem tersebut.

b) Generate yang telah dilaksanakan sebaiknya tidak dilakukan proses batal tambah kembali.

c) Adanya Rencana penambahan slot pada penjadwalan yang terjadi semula 15 slot mengalami perubahan menjadi 17 slot.

2. Dengan metode Auto Generate Time Table dapat meningkatkan ketelitian dalam melakukan sistem penjadwalan yang sesuai dengan tabel perencanaan yang dilakukan bagian penjadwalan.

3. Hasil penjadwalan yang dilakukan menggunakan standar STMIK Raharja, sedangkan lainnya dapat diimplementasikan dikampus lain yang disesuaikan kebutuhan.

4. Hasil implementasi sistem penjadwalan yang dilakukan pada sistem online jadwal rencana semester (OJRS) memudahkan bagian administrasi pada divisis akademik dalam mempersiapkan rencana perkuliahan di awal semester.

5. Dengan demikian mahasiswapun dapat melakukan rencana perkuliahan dengan mengisi form Kartu Studi Tetap (KST) dan selanjutnya melakukan proses batal tambah diakiri dengan terbitnya Kartu Studi Tetap Final (KSTF).

\section{Ucapan terima kasih}

Penelitian ini dapat berlangsung baik karena dibiayai oleh skim Penelitian Dosen Pemula (PDP) Direktorat Penelitian dan Pengabdian kepada Masyarakat (DP2M) - DIKTI anggaran tahun 2018, oleh karena itu kami mengucapkan terima kasih kepada DP2M - DIKTI mengenai pendanaan penelitian.

\section{DAFTAR PUSTAKA}

1. Ariani, D., Fahriza, A., \& Prasetyaningrum, I. (2011). Optimasi Penjadwalan Mata Kuliah di Jurusan Teknik Informatika Pens dengan Menggunakan Algoritma Particle Swarm Optimization (PSO). EEPIS Repository, 1-11.

2. Aziz, A. (2015). Optimasi Penjadwalan Perkuliahan Menggunakan Metode Simulated Annealing (Studi Kasus: Program Studi Teknik Informatika Universitas Yudharta Pasuruan). EXPLORE IT: Jurnal Keilmuan Dan Aplikasi Teknik Informatika, 7(2).

3. Chu, S., \& Chen, Y. (2006). Timetable Scheduling Using Particle Swarm Optimization. IEEE Xplore, 
0-3. https://doi.org/10.1109/ICICIC.2006.541

4. Gani, T. A. (2004). Optimizing examination timetabling using a hybrid evolution strategies Optimizing Examination Timetabling using a Hybrid Evolution Strategies. 2nd International Conference on Autonomous Robots and Agents, (June 2017), 345-349.

5. Gunawan, C. A., \& Toba, H. (2016). Pembangkitan Solusi Penjadwalan Berprioritas Melalui Penerapan Constraint Satisfaction Problem (Studi Studi Kasus: Laboratorium Fakultas Teknologi Informasi Universitas XXX ). Jurnal Teknik Informatika Dan Sistem Informasi, 2(April), 43-52.

6. Islam, T., Shahriar, Z., Perves, M.A. and Hasan, M. (2016). University Timetable Generator Using Tabu Search. Journal of Computer and Communications, 4, 28-37. https://doi.org/10.4236/jcc.2016.416003

7. Kumar, K., Sharma, R., \& Mehta, K. (2012). Genetic Algorithm Approach to Automate University Timetable, 1(1).

8. Montero, E. (2011). A PSO algorithm to solve a Real Course + Exam Timetabling Problem. International Conference on Swarm Intelligence, 2, 1-9.

9. Norberciak, M. (2008). Universal Method for Timetable Construction based on Evolutionary Approach. International Journal of Social, Behavioral, Educational, Economic, Business and Industrial Engineering, 2(3), 174-179.

10. Poole, L., David, Alan K., M. (2010). Artificial Intelligence: Foundations of Computational Agents. UK: Cambridge University Press. Retrieved from www.cambridge.org/9780521519007

11. Pressman, R. S. (2010). Software Engineering : A Prectitioner's Approach. (F. M. Schilling, Ed.) (7th ed.). New York: McGraw-Hill.

12. Putri, Y. (2014). Pemanfaatan Matriks Jarang dengan Metode Algoritma Genetika Menggunakan Program Pascal. Jurnal Matematika UNAND, 3(1), 98-106.

13. Siswono, T. (2013). Kombinasi Algoritma Genetika dengan Algoritma Palgunadi untuk Penjadwalan Mata Kuliah di Universitas Sebelas Maret. ITSMart, 2(2), 7-12. https://doi.org/http://dx.doi.org/10.20961/its.v2i2.624

14. Warsito, A. B., \& Yusup, M. (2014). Kajian Yii Framework dalam Pengembangan Website Perguruan Tinggi. CCIT Journal, 7(40), 437-451. Retrieved from http://raharja.ac.id/acid/karyailmiah/karyailmiah/view/id/7030814

15. Yudihartanti, Y., Syukur, A., \& Wahono, R. S. (2011). Analisis Komparasi Metode Mamdani dan Sugeno dalam Penjadwalan Mata Kuliah. Jurnal Teknologi Informasi, 7(2), 109-116. 